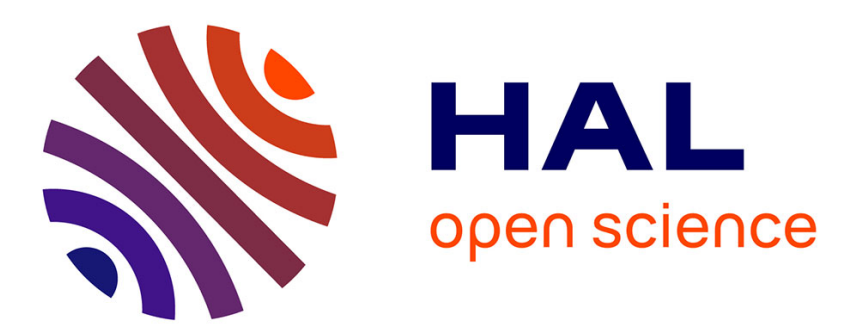

\title{
Assessment of pollution in the west black sea coast of turkey using biomarker responses in fish
}

\author{
Azra Bozcaarmutlu, Canan Sapmaz, Zuleyha Aygun, Emel Arinç
}

\section{To cite this version:}

Azra Bozcaarmutlu, Canan Sapmaz, Zuleyha Aygun, Emel Arinç. Assessment of pollution in the west black sea coast of turkey using biomarker responses in fish. Marine Environmental Research, 2009, 67 (4-5), pp.167. 10.1016/j.marenvres.2008.12.009 . hal-00563067

\section{HAL Id: hal-00563067 https://hal.science/hal-00563067}

Submitted on 4 Feb 2011

HAL is a multi-disciplinary open access archive for the deposit and dissemination of scientific research documents, whether they are published or not. The documents may come from teaching and research institutions in France or abroad, or from public or private research centers.
L'archive ouverte pluridisciplinaire HAL, est destinée au dépôt et à la diffusion de documents scientifiques de niveau recherche, publiés ou non, émanant des établissements d'enseignement et de recherche français ou étrangers, des laboratoires publics ou privés. 


\section{Accepted Manuscript}

Assessment of pollution in the west black sea coast of turkey using biomarker responses in fish

Azra Bozcaarmutlu, Canan Sapmaz, Zuleyha Aygun, Emel Arinç

PII:

S0141-1136(09)00002-6

DOI:

10.1016/j.marenvres.2008.12.009

Reference:

MERE 3313

To appear in:

Marine Environmental Research

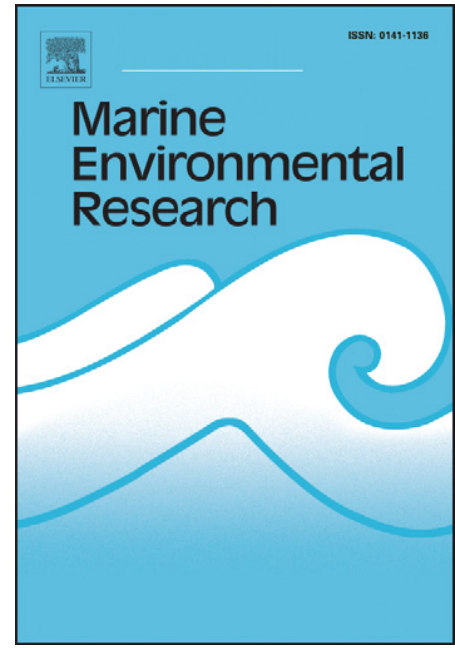

Received Date: $\quad 9$ September 2008

Revised Date: $\quad 29$ December 2008

Accepted Date: $\quad 30$ December 2008

Please cite this article as: Bozcaarmutlu, A., Sapmaz, C., Aygun, Z., Arinç, E., Assessment of pollution in the west black sea coast of turkey using biomarker responses in fish, Marine Environmental Research (2009), doi: 10.1016/ j.marenvres.2008.12.009

This is a PDF file of an unedited manuscript that has been accepted for publication. As a service to our customers we are providing this early version of the manuscript. The manuscript will undergo copyediting, typesetting, and review of the resulting proof before it is published in its final form. Please note that during the production process errors may be discovered which could affect the content, and all legal disclaimers that apply to the journal pertain. 
2

3

4

5

6

7

8

9

10

11

12

13

\section{ASSESSMENT OF POLLUTION IN THE WEST BLACK SEA COAST OF TURKEY USING BIOMARKER RESPONSES IN FISH}

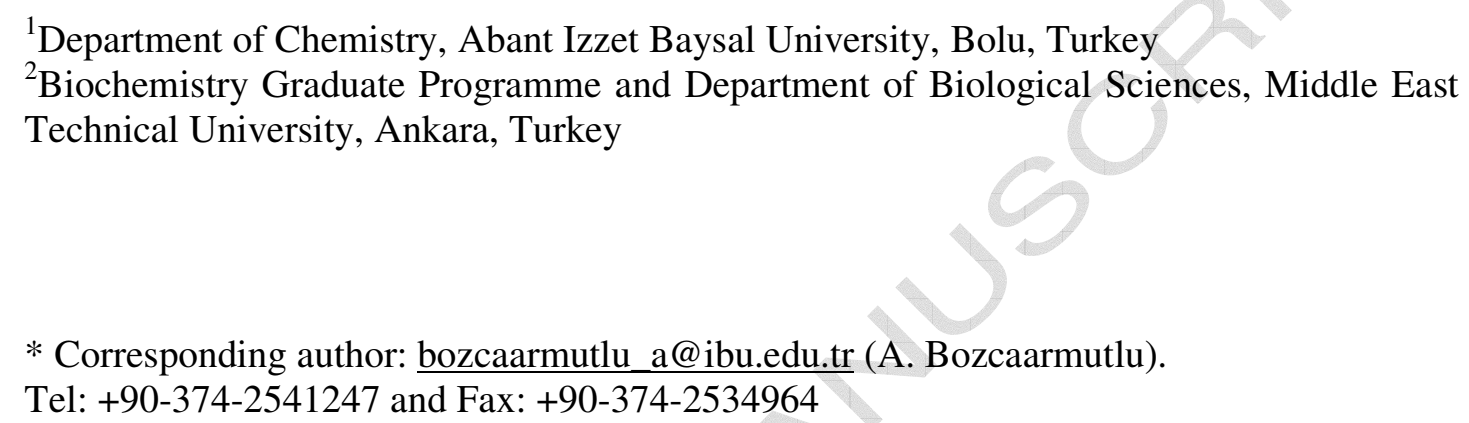




\section{ABSTRACT}

Aim of this study was to determine the extent of pollution in the West Black Sea Coast of Turkey by measuring CYP1A associated EROD activity, phase II enzyme, glutathione Stransferase and antioxidant enzymes, catalase and glutathione reductase activities and immunochemical detection of CYP1A protein level in the liver of mullet. The fish samples were caught from six locations having a varying degree of pollution in the West Black Sea Region of Turkey in August 2005, 2006 and 2007. Mullets caught from Zonguldak Harbour, Ereğli Harbour and Gülüç Stream's Mouth displayed 6-9 fold higher EROD, 2-4 fold higher glutathione S-transferase and 2-3 fold higher catalase activities than the reference site, Amasra. Total polyaromatic hydrocarbon levels in mullets caught from these locations were also significantly higher (2-4 fold) than Amasra. The results of this study indicate that Zonguldak Harbour, Ereğli Harbour and Gülüç Stream are highly polluted by polycyclic aromatic hydrocarbons and related contaminants.

Keywords: Black Sea, Biomonitoring, CYP1A, Catalase, Chemical pollution, EROD, Glutathione S-transferase, Mullet. 


\section{INTRODUCTION}

The Black Sea has been increasingly threatened by pollutants over the past decades as a result of accidental crude oil spills, dumping of toxic industrial wastes, discharge of domestic wastes from coastal settlements and industrial and domestic pollutants carried by rivers. Some industrial areas, rivers and coastal cities in the Black Sea have tendency to create local pollution (Mee, 1992). The Sakarya River, from its source in the West Anatolia, flows through many industrial and agricultural areas and drains into the Black Sea. It carries many pollutants to the Black Sea from inner regions of Turkey (Tuncer et al., 1998; Barlas, 1999). Industrial areas found in Düzce and Adapazarı drain their discharges into Efteni Lake. The Melen Stream originates from this lake and flows through many industrial and agricultural areas. The Gülüç Stream is very close to the Ereğli Harbour and Ereğli Iron and Steel Factory. This small stream was highly polluted primarily by domestic waste discharges from Ereğli and villages around the stream. Zonguldak and Ereğli, with increasing population, shipping activities, uncontrolled discharges from industries and coastal settlements, are among the most polluted regions in the Black Sea. Zonguldak is also an important coal mining area in Turkey. It suffers from particulate discharges from the thermal power plant and coal processing wastes, resulting in permanently elevated turbidity levels along the coast of the city (Tuncer et al., 1998).

Chemical analyses of the sea water and sediment give valuable information about the levels of chemical pollutants. However, organisms are often exposed to complex mixtures of pollutants, including polychlorinated biphenyls (PCBs), polychlorinated dibenzodioxins (PCDDs), polychlorinated dibenzofurans (PCDFs), polyaromatic hydrocarbons (PAHs), alkyltin compounds, and metals. Chemical analyses do not reveal the impact of these pollutants on organisms. The use of biochemical markers fulfills this purpose. Induction of CYP1A (P4501A) and associated EROD activity are the best characterized and used biochemical markers of exposure of fish to organic pollutants such as PCBs, PAHs and dioxins. CYP1A induction provides a useful "tool" for the assessment of exposure to these types of organic pollutants and acts as an early warning sign for potential harmful effects of many organic molecules (Payne et al., 1987; Goksøyr and Förlin, 1992; Bucheli and Fent, 1995; Stegeman, 1995; Addison, 1996; Arinç and Sen, 1999; Miller et al., 2003; Arinç et al., 2000, 2001). Glutathione-S-transferases (GSTs) catalyse the conjugation of electrophilic compounds (or phase I metabolites) with reduced glutathione (GSH) and are one of the main enzymes involved in xenobiotic phase II metabolism. GSTs detoxify a number of environmental carcinogens and epoxide intermediates (Gallagher et al., 1996). Glutathione S-transferase activity measurement is also used as a marker of oxidative stress (Rodriguez-Ariza et al., 1993; Martínez- Gómez et al., 2006). The induction of antioxidant enzyme activities represents a cellular defense mechanism to neutralize toxic effects of reactive oxygen species. Benzo[ $a]$ pyrene as well as other PAHs and PCBs have been shown to cause significant alterations in the activities of antioxidant enzymes in laboratory experiments with molluscs and fish (Otto and Moon, 1995, Van der Oost et al., 2003). Changes in the levels of phase II enzymes, glutathione Stransferase and antioxidant enzymes have also been proposed as biomarkers of contaminants in a variety of marine organisms, including invertebrates, mussels, and fish (Otto and Moon, 1995, Livingstone, 2001; Orbea et al., 2002; Sen and Kirikbakan, 2004; Ferreira et al., 2005; Martínez- Gómez et al., 2006).

The studies concerning the effects of pollutants on the Black Sea ecosystem are relatively few (Telli-Karakoç et al., 2001; Bozcaarmutlu et al., 2006, 2008). Monitoring 



\section{MATERIALS AND METHODS}

\subsection{Chemicals}

Acrylamide, anti-rabbit IgG alkaline phosphatase antibody, $\varepsilon$-amino caproic acid (ع-ACA), 7-ethoxyresorufin, N-2-hydroxyethylpiperazine-N'-2-ethansulphonic acid (HEPES), $\beta$-mercaptoethanol, N,N'-methylene bisacrylamide, phenylmethanesulfonyl fluoride (PMSF), resorufin sodium salt were purchased from Sigma-Aldrich, Saint Louis, Missouri, USA. Bromophenol blue, N,N-dimethylformamide and nitro blue tetrazolium chloride were purchased from Merck, Darmstadt, Germany. 5-bromo-4-chloro-3indolylphosphate disodium salt (BCIP), glucose-6-phosphate dehydrogenase, $\alpha$-D-glucose6-phosphate monosodium salt, polyethylene sorbitan monolaurate (Tween 20), sodium dodecyl sulfate (SDS) were purchased from Calbiochem, California, USA. Ammonium persulfate, N, N, N', N' tetrametylethylene diamine (TEMED), trans blot tranfer medium (pure nitrocellulose membrane) were purchased from Bio-Rad Laboratories, California, USA. $\beta$-Nicotinamide adenine dinucleotide phosphate disodium salt $\left(\mathrm{NADP}^{+}\right), \beta-$ nicotinamide adenine dinucleotide, reduced form (NADPH), phenazine methosulfate (PMS) were purchased from Applichem, Darmstadt, Germany. All other chemicals were of analytical grade and were obtained from commercial sources at the highest grade of purity available.

\subsection{Sampling Sites and Fish}

The fish samples were collected in August 2005, August 2006 and August 2007 from six different locations of the West Black Sea Region of Turkey. The fish sampling stations were shown in Figure 1. As indicated in this figure, Amasra was used as the reference site. Three different species of mullet, namely so-iuy mullet (Mugil soiuy), flathead mullet (Mugil cephalus) and golden grey mullet (Liza aurata), each weighing 600$750 \mathrm{~g}$, were captured by fish net.

Figure 1

\subsection{Preparation of Tissue Samples}

Fish were killed by decapitation and livers were removed immediately by avoiding the gall bladders and flash frozen in liquid nitrogen. Tissues were taken from liquid nitrogen and cut into two pieces without thawing. One of the pieces was wrapped by freezing bags and covered by aluminum foil and then put back into liquid nitrogen. This piece was later used in PAH analysis. The other piece of the liver tissue was used in the preparation of microsomes and thawed on ice. Liver microsomes were prepared as described before (Adali and Arinç, 1990; Arinç and Sen, 1993) except that homogenization solution contained $10 \mathrm{mM}$ EDTA, $0.25 \mathrm{mM}$ PMSF and $0.25 \mathrm{mM} \mathrm{E}$-ACA. The homogenate was centrifuged at $13300 \times \mathrm{g}$ for 40 minutes. The microsomes were sedimented from the supernatant by centrifugation at $70000 \mathrm{xg}$ for 60 minutes. The supernatant fraction (cytosol) was removed and stored at $-80^{\circ} \mathrm{C}$ until use. The microsomal pellet was resuspended in $1.15 \% \mathrm{KCl}$ solution containing $10 \mathrm{mM}$ EDTA and resedimented by ultracentrifugation at $70000 x$ f for 50 minutes. The washed microsomes were resuspended in $10 \%$ glycerol containing $10 \mathrm{mM}$ EDTA. Aliquots of microsomes were gassed with nitrogen and stored in liquid nitrogen until used. All the procedures involved in the preparation of microsomes and cytosols were performed at $0-4^{\circ} \mathrm{C}$. 


\subsection{Biochemical Methods}

Protein concentrations of microsomes and cytosols were determined by the method of Lowry et al. (1951). Bovine serum albumin was used as a standard.

EROD activity of the mullet liver microsomes was determined by the spectrofluorometric method of Burke and Mayer (1974), with some modifications. Assay conditions optimized for gilthead seabream (Sparus aurata) liver microsomes by Arinç and Sen (1994) were also used in this study. The reaction mixture contained 0.1 M potassium phosphate buffer, $\mathrm{pH}$ 7.8, $0.1 \mathrm{M} \mathrm{NaCl}, 2.4 \mathrm{mg}$ bovine serum albumin (BSA), $1.5 \mu \mathrm{M} 7$ ethoxyresorufin, $50-100 \mu \mathrm{g}$ of fish liver microsomal protein, and $0.5 \mathrm{mM}$ NADPH generating system in a final volume of $2.0 \mathrm{~mL}$. The reaction was initiated by the addition of substrate and followed for 2 minutes in a spectrofluorometer. Finally, a known amount of resorufin was added as an internal standard to the reaction mixture and the increase in fluorescence was recorded. EROD activity was calculated using the fluorescence increase caused by the addition of resorufin.

Total glutathione S-transferase (GST) activity of mullet liver cytosols was determined according to the method of Habig et al. (1974). The reaction mixture contained $50 \mathrm{mM}$ potassium phosphate buffer, $\mathrm{pH} 7.5,1.3 \mathrm{mM}$ GSH and fish liver cytosols. The reaction was initiated by the addition of $1 \mathrm{mM}$ CDNB in a final volume of $3.0 \mathrm{~mL}$. The thioether formation was followed at $340 \mathrm{~nm}$ for 2 minutes. Specific total glutathione Stransferase activity was calculated as nmol CDNB conjugate formed $\min ^{-1} \mathrm{mg}^{-1}$ protein at $25^{\circ} \mathrm{C}$, using $9.6 \mathrm{mM}^{-1} \mathrm{~cm}^{-1}$ as an extinction coefficient $\left(\varepsilon_{340}\right)$.

Catalase (CAT) activity of mullet liver cytosols was determined according to the method of Aebi (1984). The reaction mixture contained $50 \mathrm{mM}$ potassium phosphate buffer, $\mathrm{pH}$ 7.5, $10 \mathrm{mM} \mathrm{H}_{2} \mathrm{O}_{2}$ and fish liver cytosols. The rate of reaction was followed by measuring the consumption of $\mathrm{H}_{2} \mathrm{O}_{2}$ spectrophotometrically at $240 \mathrm{~nm}$ for 1 minute. Specific catalase activity was calculated as $\mathrm{nmol} \mathrm{H}_{2} \mathrm{O}_{2}$ consumed $\min ^{-1} \mathrm{mg}^{-1}$ protein at $25^{\circ} \mathrm{C}$, using $36.4 \mathrm{mM}^{-1} \mathrm{~cm}^{-1}$ as an extinction coefficient $\left(\varepsilon_{240}\right)$.

Glutathione reductase (GR) activity of mullet liver cytosols was determined according to the method of Carlberg and Mannervick (1985). The reaction mixture contained $100 \mathrm{mM}$ potassium phosphate buffer, $\mathrm{pH}$ 7.6, $0.5 \mathrm{mM}$ EDTA, $\mathrm{pH}$ 7.6, $0.1 \mathrm{mM}$ NADPH and fish liver cytosols in a final volume of $2.0 \mathrm{~mL}$. The reaction was started by adding $1 \mathrm{mM}$ oxidized glutathione (GSSG). Then the GSH formation was followed by measuring the NADPH utilization spectrophotometrically at $340 \mathrm{~nm}$ for 5 minutes. One unit of glutathione reductase activity was calculated as nmol NADPH oxidized $\mathrm{min}^{-1} \mathrm{mg}^{-1}$ protein at $25^{\circ} \mathrm{C}$, using $6.22 \mathrm{mM}^{-1} \mathrm{~cm}^{-1}$ as an extinction coefficient $\left(\varepsilon_{340}\right)$.

\subsection{Western Blot Analysis}

Cytochrome P4501A (CYP1A) protein levels were determined using the polyclonal antibodies produced against purified leaping mullet (Liza saliens) liver cytochrome P4501A (Arinç and Sen, 1999). Western blot analysis of fish liver microsomes was carried out essentially as described by Towbin et al. (1979). Sodium dodecyl sulfatepolyacrylamide gel electrophoresis (SDS-PAGE) was performed as described by Laemmli (1970) and proteins were transferred from slab gels to nitrocellulose membrane by use of a Bio-Rad Trans-Blot electrophoretic transfer apparatus. The proteins on membranes were 
first reacted with 1:5000 diluted leaping mullet CYP1A antibodies and then with the enzyme-linked secondary antibody, and alkaline phosphatase activity was detected by the method of Ey and Ashman (1986). The final images of the blots were photographed using a computer-based gel imaging instrument (Infinity 3000-CN-3000 darkroom, Vilber Lourmat, Marne-la-Vallee Cedex 1, France), and relative peak area (R.P.A.) of the blots was analyzed using the Scion Image software for Windows (Version 4.0.2, Scion Corporation, Maryland, USA) as a quantitative tool to determine CYP1A protein levels.

\subsection{PAH Analysis}

Spectrofluorometric measurements of the total PAH concentration in fish liver tissues were performed according to the method described by UNEP, 1992. The principle of the method is based on the extraction of PAHs by suitable pure solvent. Mullet livers were dried in an oven at $40{ }^{\circ} \mathrm{C}$ overnight. Dried tissue $(0.2 \mathrm{~g})$ was ground and refluxed with $20 \mathrm{~mL}$ of ethanol containing $0.75 \mathrm{~g}$ of $\mathrm{KOH}$ for 120 minutes by constant heating. Then $20 \mathrm{~mL}$ of PAH-free hexane was added to the flask and mixed very well and waited until the flask reached to room temperature. When the flask was attained to room temperature, it was poured into a separatory funnel and sufficient amount of distilled water was added. The lower aqueous phase was extracted further two times with $20 \mathrm{~mL}$ of PAHfree hexane. The fluorescence intensities of the pooled samples were measured at $310 \mathrm{~nm}$ excitation and $360 \mathrm{~nm}$ emission wavelengths. The fluorescence intensity of the pooled samples was compared with the fluorescence intensity of known concentrations of chrysene standard.

\subsection{Statistical Analysis}

Results were expressed as means \pm standard error of the mean (S.E.M.). Data were analyzed by two-way ANOVA using years and sampling sites as independent variables. When significant differences were observed, Tukey HSD Post Hoc Test was applied for a pair-wise comparison. The analyses were carried out using the SPSS statistical package (SPSS 15.0 for Windows Evaluation Version). No significant sex dependent differences were observed in the fish samples. Therefore the data were pooled. 


\section{RESULTS}

In this study 147 fish samples were collected from six different locations of the West Black Sea Coast of Turkey. In all samples, EROD, glutathione S-transferase, catalase and glutathione reductase activities were measured. Table 1 illustrates biomarker enzyme activity results. The lowest biomarker activities were measured in fish samples (so-iuy mullet, flathead mullet and golden grey mullet) caught from Amasra. The biomarker enzyme activities of different mullet species were compared with the corresponding mullet species caught from Amasra. This relatively clean site was considered as a reference site to demonstrate the extent of pollution.

\section{Table 1}

\subsection{7-Ethoxyresorufin O-deethylase (EROD) Activity and CYPIA Protein Level}

The highest EROD activities were found in mullets (so-iuy mullets, flathead mullets, and golden grey mullets) caught from Zonguldak Harbour in all sampling years (Table 1). Mullets caught from Zonguldak Harbour had about 6-9 fold higher EROD activities than those obtained from Amasra. The highly elevated EROD activities were also measured in mullets captured from Ereğli Harbour which were about 7-9 fold higher with respect to the values obtained from Amasra. Gülüç Stream's Mouth was the other highly polluted station in this study. EROD activities of mullets samples caught from this station were about 6 fold higher than those obtained from Amasra. In Figure 2, the data were presented separately for each species. Statistically significant differences were indicated in this figure with different letters $(\mathrm{p}<0.05)$. EROD activities of soiuy mullets caught from Zonguldak Harbour and Gülüç Stream's Mouth were significantly different from the souiy mullets caught from Amasra, Melen Stream's and Sakarya River's Mouths. EROD activities of flathead mullets caught from Zonguldak Harbour were significantly different from Amasra. EROD activities of golden grey mullets caught from Zonguldak and Ereğli Harbours were significantly different from Amasra. EROD activities of mullets caught from Melen Stream's Mouth were 2 fold higher than Amasra, however these differences were not statistically significant. Significant differences between years were not found in EROD activities of fish caught from all sampling stations except Sakarya River's Mouth.

Figure 2

CYP1A protein level was also determined in mullet liver microsomes using the polyclonal antibodies produced against leaping mullet cytochrome P4501A. Figure 3 illustrates the western blot analysis results of mullets caught from six different stations in three sampling years. Polyclonal antibody anti-leaping mullet cytochrome P4501A showed strong cross-reactivity with liver microsomes of so-iuy mullets, flathead mullets and golden grey mullets caught from different stations of the West Black Sea. The CYP1A bands of mullets caught from Zonguldak and Ereğli Harbours and Gülüç Stream's Mouth were stained more intensely than those obtained from Amasra. Liver microsomes of mullets caught from Melen Stream's Mouth and Sakarya River's Mouth showed moderate cross reactivity with polyclonal anti-mullet P4501A. Liver microsomes of mullets caught from Amasra showed low cross-reactivity with polyclonal antibody anti-mullet P4501A. The results clearly indicated that mullets caught from the polluted sites had both highly induced EROD activity and elevated CYP1A protein content. The relationship between CYP1A protein levels and EROD activities was also examined with correlation analysis 
(Figure 3). CYP1A protein levels were highly correlated with the EROD activity results in the mullet samples caught from different stations of the West Black Sea Coast of Turkey $\left(\mathrm{R}^{2}\right.$ ranged between 0.92-0.96).

Figure 3

When EROD activities of different mullet species were analyzed using ANOVA, species differences were not significant $(\mathrm{p}=0.714)$. When the species specific crossreactivity pattern of anti-leaping mullet CYP1A protein was compared, different mullet species having similar EROD activity showed similar degree of staining and gave almost the same EROD activity/CYP1A protein level (R.P.A.) ratio (Figure 4). The induction responses to organic pollutants, both with respect to EROD activities and CYP1A protein levels, were not different between these mullet species.

Figure 4

\subsection{Glutathione S-transferase Activity}

The highest total glutathione S-transferase activities were measured in mullets caught from Zonguldak Harbour in all sampling years which were about 4 fold higher than those obtained from Amasra (Table 1). Mullets caught from Gülüç and Melen Streams' Mouths also displayed highly elevated total glutathione S-transferase activities which were 3-4 fold higher than those obtained from Amasra. In Figure 5, the data were presented separately for each species. Glutathione S-transferase activities of soiuy mullets caught from Zonguldak Harbour, Melen and Gülüç Streams' Mouths were not significantly different from each other. However, they were significantly different from Amasra. Glutathione S-transferase activities of soiuy mullets caught from Sakarya River's Mouth (represented by "ab") were not statistically different from Zonguldak Harbour, Gülüç and Melen Stream's Mouths and Amasra. Glutathione S-transferase activities of golden grey mullets caught from Ereğli Harbour (represented by "ab") were 2-3 fold higher than those obtained from Amasra, however these differences were not significantly different from Amasra and Zonguldak Harbour. Glutathione S-transferase activities of mullets caught from Ereğli Harbour showed significant difference between years. The highest GST activities were measured in the fish samples caught in 2005.

Figure 5

\subsection{Catalase Activity}

The highest catalase activities were detected in mullets caught from Sakarya River's and Melen Stream's Mouths and Zonguldak Harbour in 2005, which were about 3 fold higher than those obtained from Amasra (Table 1). Fish sampled from Gülüç Stream's Mouth also displayed highly elevated catalase activities which were 2 fold higher than those obtained from Amasra. In Figure 6, the data were presented separately for each species. Catalase activities of soiuy mullets caught from Zonguldak Harbour, Melen Stream's and Sakarya River's Mouths were not statistically different from each other. However, they were significantly different from Amasra. Catalase activities of soiuy mullets caught from Gülüç Stream's Mouth (represented by "ab") were not statistically different from Zonguldak Harbour, Melen Stream's and Sakarya River's Mouths and Amasra. Catalase activities of flathead mullets caught from Zonguldak Harbour were 
significantly different from Amasra. Catalase activities of golden grey mullets caught from Zonguldak and Ereğli Harbours were significantly different from Amasra. Although highly elevated catalase activities were measured in mullets caught in 2005, this enzyme activity significantly decreased in the mullets caught from Melen Stream's and Sakarya River's Mouths and Ereğli Harbour in the following sampling years.

Figure 6

\subsection{Glutathione Reductase Activity}

Highly elevated glutathione reductase activities were measured in mullets caught from Zonguldak and Ereğli Harbours, Gülüç and Melen Streams' Mouths (Table1). In 2005, mullets caught from Melen Stream's Mouth had the highest glutathione reductase activities among the other sampling sites which were 1.7 fold higher than those obtained from Amasra. Glutathione reductase activities of mullets caught from Gülüç Stream's Mouth were 1.6 fold higher than those obtained from Amasra in 2005 and 2006. Glutathione reductase activities of mullets captured from Ereğli Harbour were 1.6 fold higher than those obtained from Amasra. In 2006, glutathione reductase activities of so-iuy mullets and golden grey mullets captured from Zonguldak Harbour were 1.5 and 1.4 fold higher than those obtained from Amasra, respectively. In Figure 7, the data were presented separately for each species. Glutathione reductase activities of soiuy mullets caught from Melen and Gülüç Streams' Mouths were significantly different from Amasra and Sakarya River's Mouth. Glutathione reductase activities of soiuy mullets caught from Zonguldak Harbour (represented by "ab") were not statistically different from Gülüç, Melen Streams', Sakarya River's Mouths and Amasra. Glutathione reductase activities of golden grey mullets caught from Zonguldak and Ereğli Harbours were significantly different from Amasra. Significant differences between years were not found in glutathione reductase activities of fish caught from all sampling stations except Sakarya River's Mouth.

Figure 7

\subsection{PAH Analysis}

Besides biomarker enzyme activity measurements, total PAH concentrations were determined in mullets caught in 2006 to show the presence and extent of one of the organic pollutants in the sampling stations. Table 2 illustrates the total PAH concentrations in mullet liver tissues. The highest total PAH concentrations were measured in mullets caught from Zonguldak Harbour. Total PAH concentrations of fish caught from Zonguldak and Ereğli Harbours and Gülüç Stream's Mouth were significantly different from Amasra. Total PAH concentrations of fish caught from Zonguldak Harbour were significantly different from fish caught from Ereğli Harbour. However, total PAH concentrations of fish caught from Ereğli Harbour and Gülüç Stream's Mouth were not significantly different from each other. The lowest total PAH concentrations were measured in mullets caught from Amasra. Total PAH concentrations of fish caught from Sakarya River's and Melen Stream's Mouths (represented as "bc") were not significantly different from Amasra, Ereğli Harbour and Gülüç Stream’s Mouth.

Table 2

498 
The relationship between biomarker activities and total PAH concentrations was also examined with correlation analysis (Pearson). The highest positive correlation was

502 found between EROD activities and total PAH concentrations $(r=0.491, \mathrm{p}<0.01)$.

503 Glutathione reductase and glutathione S-transferase activities were slightly correlated with 504 total PAH concentrations $((r=0.392, \mathrm{p}<0.01)$ and $(r=0.283, \mathrm{p}<0.05)$, respectively $)$. 505 Correlation between total PAH concentrations and catalase activities was positive but not 506 significant $(r=0.210, \mathrm{p}=0.083)$.

507

508

509

510

511

512

513

514

515

516

517

518

519

520

521

522

523

524

525

526

527

528

529

530

531

532

533

534

535

536

537

538

539

540

541

542

543

544

545

546

547

548

549 


\section{DISCUSSION}

In this study, cytochrome P4501A (CYP1A) associated EROD activity, phase II enzyme, glutathione S-transferase and antioxidant enzymes, catalase and glutathione reductase activities were measured in mullet liver fractions to determine and monitor the extent of pollution in the West Black Sea Coast of Turkey. Highly elevated biomarker enzyme activities were found in the mullets caught from Zonguldak and Ereğli Harbours, and Gülüç Stream's Mouth. Zonguldak is an important coal mining area in Turkey. The harbour of this city is polluted especially with coal processing wastes and discharges of industrial and domestic wastes. Cohen and coworkers (1994) have shown that coal byproducts such as coal-tar significantly induce EROD activity in medika liver. In addition, Vignier and coworkers (1994) have demonstrated that EROD activity significantly increases in winter flounder in coal-tar contaminated estuary. Creosote is a dark liquid made from coal tar. It is a complex mixture of organic compounds, containing about $85 \%$ PAHs. Hyötyläinen and Oikari (1999) and Whyte and coworkers (2000) have demonstrated in different studies that the extracts of creosote-contaminated sediments highly induce EROD activities in rainbow trout. In this study, the lowest biomarker enzyme activities were measured in mullets caught from Amasra. The biomarker enzyme activities obtained from the other stations were compared with those obtained from Amasra. 6-9 fold increase in EROD activities and elevated CYP1A protein levels were found in mullets caught from Zonguldak Harbour with respect to Amasra. This result clearly indicates that coal mining activities create pollution in Zonguldak Harbour.

İzmir Bay is one of the most polluted sites in Turkey. Highly elevated EROD activities have been reported in mullets (Liza saliens and Mugil cephalus) caught from the most polluted site of İzmir Bay. In these studies, EROD activities of Liza saliens were reported as $1293 \pm 292 \mathrm{pmol} \mathrm{min}^{-1} \mathrm{mg}^{-1}$ protein in 1995 and $1028 \pm 287 \mathrm{pmol} \mathrm{min}^{-1} \mathrm{mg}^{-1}$ protein in 1999 (Arinç and Sen, 1999; Arinç et al., 2000). EROD activities of Mugil cephalus caught from the same site were $1398 \pm 410 \mathrm{pmol} \mathrm{min}^{-1} \mathrm{mg}^{-1}$ protein in 1999 (Arinç et al., 2000). In our study, highly elevated EROD activities were found in mullets caught from Zonguldak and Ereğli Harbours, and Gülüç Stream's Mouth, suggesting the presence of organic pollutants such as PAHs and PCBs in these sampling stations in the West Black Sea Coast of Turkey.

Glutathione S-transferases are involved in the detoxification reactions of xenobiotics. Induction of glutathione S-transferase have been reported in a number of field studies in fish exposed to organic contaminants (Lenartova et al., 1997; Pandey et al., 2003; Martínez- Gómez et al., 2006; Sen and Kirikbakan, 2004). In our study, highly elevated total glutathione S-transferase activities measured in mullets caught from Zonguldak Harbour (950-1147 $\mathrm{nmol} \mathrm{min}^{-1} \mathrm{mg}^{-1}$ protein), Ereğli Harbour (932 $\pm 131 \mathrm{nmol}$ $\mathrm{min}^{-1} \mathrm{mg}^{-1}$ protein), Gülüç Stream's Mouth $\left(1352 \pm 154 \mathrm{nmol} \mathrm{min} \mathrm{mg}^{-1}\right.$ protein) and Melen Stream's Mouth $\left(1192 \pm 140 \mathrm{nmol} \mathrm{min}{ }^{-1} \mathrm{mg}^{-1}\right.$ protein) are at the same order of magnitude of that reported by Sen and Kirikbakan (2004) in mullets (Liza saliens) caught from highly polluted site of İzmir Bay in Turkey $\left(1183 \pm 35.9 \mathrm{nmol} \mathrm{min}^{-1} \mathrm{mg}^{-1}\right.$ protein).

Chronic exposure to organic pollutants increases reactive oxygen species (ROS) formation (Livingstone 2001). The antioxidant enzyme catalase is one of the most responsive enzymes to ROS (Halliwell and Gutteridge, 1999). Elevated catalase enzyme activities have been reported in several fish species in various laboratory and field studies (Otto and Moon, 1995, Orbea et al., 2002; Ferreira et al., 2005). Significantly high catalase 
600

601

602

603

604

605

606

607

608

609

610

611

612

613

614

615

616

617

618

619

620

621

622

623

624

625

626

627

628

629

630

631

632

633

634

635

636

637

638

639

640

641

642

643

644

645

646

647

648

649 activities were measured in mullets caught from Zonguldak and Ereğli Harbours and Melen Stream's and Sakarya River's Mouths, indicating the presence of ROS generating pollutants in these regions. The other biomarker enzyme activity measured in this study was glutathione reductase. Glutathione reductase maintains GSH/GSSG homeostasis under oxidative stress conditions. Induction of glutathione reductase activity have been reported in various field studies in fish exposed to organic pollutants such as PAHs, PCBs and halogenated xenobiotics (Rodriguez-Ariza et al., 1993; Van der Oost et al., 2003; Martínez- Gómez et al., 2006). Significantly high glutathione reductase activities have been found in mullets caught from Zonguldak and Ereğli Harbours, Gülüç and Melen Streams' Mouths, suggesting the presence of PAHs, PCBs and halogenated xenobiotics in these sampling sites.

Biomarker enzyme activities of fish caught from Sakarya River's Mouth displayed significant differences between sampling years. Sakarya River is the third longest river of Turkey $(824 \mathrm{~km})$. It rises from the center of Anatolia and joins with Porsuk, Göksu, Kirmir, Mudurnu and Çark Streams. The river runs through many industrial and agricultural areas before reaching to the Black Sea. The results of this study suggested the existence of qualitative and quantitative differences of contaminants in the sampling station between years. However, it is difficult to determine which chemicals specifically affected the biomarker activities in the environmental monitoring studies. Biomarkers reveal the interactive effects of chemical contaminants on organisms.

In the Black Sea, total PAH concentrations in fish samples have been determined by Telli-Karakoç and coworkers (2001) in mullet samples caught from Trabzon, Yomra. In our study, the highest total PAH concentrations were measured in so-iuy mullets and golden grey mullets caught from Zonguldak Harbour $\left(54 \pm 5 \mu \mathrm{g} \mathrm{g}^{-1}\right.$ dried liver weight, $\mathrm{n}=13$ and $47 \pm 6 \mu \mathrm{g} \mathrm{g}^{-1}$ dried liver weight, $\mathrm{n}=9$, respectively) are at the same order of magnitude of that reported by Telli-Karakoç and coworkers for mullets (Mugil saliens) $(55.7 \pm 16.6 \mu \mathrm{g}$ $\mathrm{g}^{-1}$ dried liver weight) caught from Trabzon, Yomra. In our study, significantly high total PAH concentrations were also measured in mullets caught from Ereğli Harbour and Gülüç Stream's Mouth. The sampling areas arranged in decreasing order of total PAH concentrations are Zonguldak Harbour $>$ Gülüç Stream Mouth $>$ Ereğli Harbour $>$ Melen Stream Mouth $>$ Sakarya River Mouth $>$ Amasra.

The relationship between biomarker activities and total PAH concentrations was also analyzed. Biomarker activities of fish were moderately related with total PAH concentrations, suggesting the presence of the other organic contaminants such as PCBs and/or dioxins in these regions besides polycyclic aromatic hydrocarbons.

\section{CONCLUSION}

In this study, the contribution of Turkish rivers and harbours present in the West Black Sea Region of Turkey to the pollution of the Black Sea was assessed using biomarker responses of fish. The elevated biomarker responses found in this study indicate that Zonguldak Harbour, Ereğli Harbour and Gülüç Stream are highly polluted by polycyclic aromatic hydrocarbons and related contaminants. In addition, Melen Stream and Sakarya River also bring some PAHs, PCBs and other type of pollutants from the inner parts of Anatolia and Black Sea Region of Turkey. The results reported here also supported the conclusion of previous field studies that mullet is a suitable fish species for biomonitoring studies. 
650

651

652

653

654

655

656

657

658

659

660

661

662

663

664

665

666

667

668

669

670

671

672

673

674

675

676

677

678

679

680

681

682

683

684

685

686

687

688

689

690

691

692

693

694

695

696

697

698

699

\section{ACKNOWLEDGMENTS}

The authors thank all the members of the Ministry of Agriculture and Rural Affairs (Tarim ve Koy Isleri Bakanligi, Turkey) for their help in collecting the fish. They also would like to thank Munire Ozlem Cevik and Asiye Kumru for their technical support in the statistical analysis and Serif Akman for his help for providing some laboratory equipments. This research was supported by TUBITAK (The Scientific and Technological Research Council of Turkey) (Project No:104Y083).

(1)

(1)

(6)




\section{REFERENCES}

708

709

710

711

712

713

714

715

716

717

718

719

720

721

722

723

724

725

726

727

728

729

730

731

732

733

734

735

736

737

738

739

740

741

742

743

744

745

746

747

748

749
Adali, O., Arinç, E., 1990. Electrophoretic, spectral, catalytic and immunochemical properties of highly purified cytochrome-P450 from sheep lung. International Journal of Biochemistry 22, 1433-1444.

Addison, R.F., 1996. The use of biological effects monitoring in studies of marine pollution. Environmental Reviews 4, 225-237.

Aebi, H., 1984. Catalase in vitro. Methods in Enzymology 105, 121-126.

Arinç, E., Sen, A., 1993. Characterization of cytochrome P450 dependent mixed function oxidase system of gilthead seabream (Sparus aurata; Sparidae) liver. Comparative Biochemistry and Physiology 104B, 133-138.

Arinç, E., Sen, A., 1994. Effects of in vivo benzo[a]pyrene treatment on liver microsomal mixed-function oxidase activities of gilthead seabream (Sparus aurata). Comparative Biochemistry and Physiology 107C, 405- 414.

Arinç, E., Sen, A., 1999. Hepatic cytochrome P4501A and 7-ethoxyresorufin O-deethylase induction in mullet and common sole as an indicator of toxic organic pollution in İzmir Bay, Turkey. Marine Environmental Research 48, 147-160.

Arinç, E., Sen, A., Bozcaarmutlu, A., 2000. Cytochrome P4501A and associated MFO induction in fish as a biomarker for toxic, carcinogenic pollutants in the aquatic environment. Pure and Applied Chemistry 72, 985-994.

Arinç, E., Kocabiyik, S., Su, E., 2001. Induced CYP1A mRNA, protein and catalytic activity in the liver of feral fish, leaping mullet, Liza saliens. Comparative Biochemistry and Physiology 128C, 281-290.

Barlas, N., 1999. A pilot study of heavy metal concentration in various environments and fishes in the upper Sakarya River basin, Turkey. Environmental Toxicology 14, 367-373.

Bozcaarmutlu, A., Arinç, E., 2004. Inhibitory effects of divalent metal ions on liver microsomal 7-ethoxyresorufin O-deethylase (EROD) activity of leaping mullet. Marine Environmental Research 58, 521-524.

Bozcaarmutlu, A., Aygun, Z., Sapmaz, C., Arinç, E., 2006. Biomonitoring of the toxic pollutants by using mullet liver enzymes in the West Black Sea Region of Turkey. The FEBS Journal 273, 291-292.

Bozcaarmutlu, A., 2007. Mechanism of inhibition of purified leaping mullet (Liza saliens) NADPH-cytochrome P450 reductase by toxic metals: aluminum and thallium. Journal of Biochemical and Molecular Toxicology 21, 340-347.

Bozcaarmutlu, A., Arinç, E., 2007. Effect of mercury, cadmium, nickel, chromium and zinc on kinetic properties of NADPH-cytochrome P450 reductase purified from leaping mullet (Liza saliens). Toxicology in Vitro 21, 408-416. 
Bozcaarmutlu, A., Sapmaz, C., Aygun, Z., Arinç, E., 2008. Biomarker responses in so-iuy mullet (Mugil so-iuy) to toxic organic pollutants in the West Black Sea Region of Turkey. Marine Environmental Research 66, 172.

Bozcaarmutlu, A., Arinç, E., 2008. Purification of CYP2B-like protein from feral leaping mullet (Liza saliens) liver microsomes and its biocatalytic, molecular, and immunological characterization. Journal of Biochemical and Molecular Toxicology 22, 284-298.

Bucheli, T.D., Fent, K., 1995. Induction of cytochrome P450 as a biomarker for environmental contamination in aquatic ecosystem. Critical Review in Environmental Science and Technology 25, 201-268.

Burke, M.D., Mayer, R.T., 1974. Ethoxyresorufin: Direct fluorometric assay of microsomal O-dealkylation which is preferentially induced by 3-methylcholanthrene. Drug Metabolism and Disposition 2, 583-588.

Carlberg, I., Mannervik, B., 1985. Glutathione reductase. Methods in Enzymology 113, 484-490.

Cohen, C., Stiller, A., Miller, M.R., 1994. Characterization of cytochrome P4501A induction in medaka (Oryzias latipes) by samples generated from the extraction and processing of coal. Archives of Environmental Contamination and Toxicology 27, 400405.

Ey, P.L., Ashman, L.K., 1986. The use of alkaline phosphatase-conjugated antiimmunoglobulin with immunoblots for determining the specificity of monoclonal antibodies to protein mixture. Methods in Enzymology 121, 497-509.

Ferreira, M., Antunes, P., Gil, O., Vale, C., Reis-Henriques, M.A., 2004. Organochlorine contaminants in flounder (Platichthys flesus) and mullet (Mugil cephalus) from Douro estuary, and their use as sentinel species for environment monitoring. Aquatic Toxicology 69, 347-349.

Ferreira, M., Moradas-Ferreira, P., Reis-Henriques, M.A., 2005. Oxidative stress biomarkers in two resident species, mullet (Mugil cephalus) and flounder (Platichthys flesus), from a polluted site in River Douro Estuary, Portugal. Aquatic Toxicology 71, 3948.

Gallagher, E.P., Stapleton, P.L., Slone, D.H., Schlenk, D., Eaton, D.L., 1996. Channel catfish glutathione S-transferase isoenzyme activity toward ( \pm )-anti-benzo[a]pyrene-trans7,8-dihydrodiol-9,10-epoxide. Aquatic Toxicology 34, 135-150.

Goksøyr, A., Förlin, L., 1992. The cytochrome P450 in fish, aquatic toxicology and environmental monitoring. Aquatic Toxicology 22, 287-312.

Habig, W.H., Pabst, M.J., Jakoby, W.B., 1974. Glutathione S-transferases: the first enzymatic step in mercapturic acid formation. Journal of Biological Chemistry 249, 71307131. 
Halliwell, B., Gutteridge, J.M.C., 1999. Free Radicals in Biology and Medicine. Oxford University Press, New York, pp. 105-245.

801

802 Hyötyläinen, T., Oikari, A., 1999. Assessment of the bioactivity of creosote-contaminated 803 sediment by liver biotransformation system of rainbow trout. Ecotoxicology and 804 Environmental Safety 44, 253-258.

805

Laemmli, U.K., 1970. Cleavage of structural proteins during the assembly of the head of bacteriophage T4. Nature 227, 680-684.

810

Lenártová, V., Holovská, K., Pedrajas, J., Martínez-Lara, E., Peinado, J., López-Barea, J., Rosival, I., Košǔth., P., 1997. Antioxidant and detoxifying fish enzymes as biomarkers of river pollution. Biomarkers 2, 247-252.

812

813

Livingstone, D.R., 2001. Contaminant reactive oxygen species production and oxidative damage in aquatic organisms. Marine Pollution Bulletin 42, 656-666.

815

Lowry, O.H., Rosebrough, N.J., Farr, A.L., Randall, R.J., 1951. Protein measurement with the Folin Phenol reagent. Journal of Biological Chemistry 193, 265-275.

Martínez- Gómez, C., Campillo, J.A., Benedicto, J., Fernández, B., Valdés, J., García, I., Sánchez, F., 2006. Monitoring biomarkers in fish (Lepidorhombus boscii and Callionymus lyra) from the northern Iberian shelf after the Prestige oil spill. Marine Pollution Bulletin $53,305-314$.

Mee, L.D., 1992. The Black-Sea in crisis- A need for concerted international action. Ambio 21, 278-286.

Miller, K.A., Addison, R.F., Bandiera, S.M., 2003. Hepatic CYP1A levels and EROD activity in English sole: biomonitoring of marine contaminants in Vancouver Harbour. Marine Environmental Research 57, 37-54.

Orbea, A., Ortiz-Zarragoitia, M., Sol'e, M., Porte, C., Cajaraville, M.P., 2002. Antioxidant enzymes and peroxisome proliferation in relation to contaminant body bordens of PAHs and PCBs in bivalve molluscs, crabs and fish from the Urdaibai and Plentzia estuarios (Bay of Biscay). Aquatic Toxicology 58, 75-98.

Otto, D.M.E., Moon, T.W., 1995. 3,3`,4,4'-tetrachlorobiphenyl effects on antioxidant enzymes and glutathione status in different tissues of rainbow trout. Pharmacology and Toxicology 77, 281-287.

Pandey, S., Parvez, S., Sayeed, I., Haque, R., Bin-Hafeez, B., Raisuddin, S., 2003. Biomarkers of oxidative stress: a comparative study of river Yamuna fish Wallago attu (B1. \& Schn.). The Science of the Total Environment 309, 105-115.

Payne, J.F., Fancey, L.L., Rahimtula, A.D., Porter, E.L., 1987. Review and perspective on the use of mixed function oxygenase enzymes in biological monitoring. Comparative Biochemistry and Physiology 86C, 233-245. 
Rodriguez-Ariza, A., Peinado, J., Pueyo, C., Lopez-Barea, J., 1993. Biochemical indicators 849 of oxidative stress in fish from polluted Littoral Areas. Canadian Journal of Fisheries and 850 Aquatic Sciences 50, 2568-2573.

Sen, A., Arinç, E., 1998a. Preparation of highly purified cytochrome P450 1A1 from leaping mullet (Liza saliens) liver microsomes and its biocatalytic, molecular and

890 Vignier, V., Vandermeulen, J.H., Singh, J., Mossman, D., 1994. Interannual mixed 891 function oxidase (MFO) activity in winter flounder (Pleuronectes americanus) from a coal 892 tar contaminated estuary. Canadian Journal of Fisheries and Aquatic Sciences 51, 1368-

895 Whyte, J.J., Karrow, N.A., Boermans, H.J., Dixon, D.G., Bols, N.C., 2000. Combined 896 methodologies for measuring exposure of rainbow trout (Oncorhynchus mykiss) to 
897 polycyclic aromatic hydrocarbons (PAHs) in creosote contaminated microcosmes. 898 Polycyclic Aromatic Compounds 18, 71-98. 
Table 1. Mean values of biomarker enzyme activities and Standard Error of Mean (SEM)

\begin{tabular}{|c|c|c|c|c|c|c|c|}
\hline Zone & Year & $\mathbf{N}$ & Fish Species & EROD $^{\mathbf{a}}$ & GST $^{\mathbf{b}}$ & $\mathbf{C A T}^{\mathbf{b}}$ & $\mathbf{G R}^{\mathbf{b}}$ \\
\hline \multirow[t]{4}{*}{ Zonguldak Harbour } & 2005 & 7 & Mugil soiuy & $3237 \pm 539$ & $1260 \pm 207$ & $322 \pm 34$ & $14.9 \pm 1.9$ \\
\hline & 2006 & 13 & Mugil soiuy & $2559 \pm 315$ & $950 \pm 135$ & $283 \pm 46$ & $20.4 \pm 0.8$ \\
\hline & 2006 & 9 & Liza aurata & $2302 \pm 240$ & $1067 \pm 208$ & $163 \pm 16$ & $16.2 \pm 1.6$ \\
\hline & 2007 & 5 & Mugil cephalus & $3017 \pm 565$ & $1017 \pm 231$ & $171 \pm 12$ & $11.5 \pm 2.1$ \\
\hline \multirow[t]{3}{*}{ Ereğli Harbour } & 2005 & 16 & Liza aurata & $1871 \pm 391$ & $932 \pm 131$ & $195 \pm 18$ & $17.4 \pm 0.7$ \\
\hline & 2006 & 12 & Liza aurata & $2037 \pm 280$ & $585 \pm 64$ & $138 \pm 12$ & $18.1 \pm 0.8$ \\
\hline & 2007 & 5 & Liza aurata & $2233 \pm 464$ & $406 \pm 29$ & $121 \pm 12$ & $17.9 \pm 1.3$ \\
\hline \multirow[t]{2}{*}{ Gülüç Stream Mouth } & 2005 & 13 & Mugil soiuy & $2402 \pm 261$ & $1352 \pm 154$ & $281 \pm 32$ & $20.8 \pm 0.9$ \\
\hline & 2006 & 11 & Mugil soiuy & $2415 \pm 426$ & $830 \pm 154$ & $224 \pm 30$ & $20.7 \pm 1.3$ \\
\hline \multirow[t]{2}{*}{ Melen Stream Mouth } & 2005 & 11 & Mugil soiuy & $1065 \pm 176$ & $851 \pm 129$ & $349 \pm 32$ & $23.1 \pm 1.9$ \\
\hline & 2006 & 9 & Mugil soiuy & $818 \pm 217$ & $1192 \pm 140$ & $200 \pm 20$ & $18.7 \pm 1.8$ \\
\hline \multirow[t]{3}{*}{ Sakarya River Mouth } & 2005 & 10 & Mugil soiuy & $904 \pm 216$ & $810 \pm 159$ & $352 \pm 17$ & $19.7 \pm 1.7$ \\
\hline & 2006 & 10 & Mugil soiuy & $438 \pm 62$ & $735 \pm 134$ & $257 \pm 32$ & $9.6 \pm 0.7$ \\
\hline & 2007 & 4 & Mugil soiuy & $1642 \pm 470$ & $1016 \pm 349$ & $187 \pm 19$ & $11.3 \pm 0.8$ \\
\hline \multirow[t]{3}{*}{ Amasra } & 2006 & 3 & Mugil soiuy & $425 \pm 18$ & $288 \pm 165$ & $123 \pm 20$ & $13.4 \pm 0.8$ \\
\hline & 2006 & 4 & Mugil cephalus & $541 \pm 22$ & $263 \pm 62$ & $117 \pm 21$ & $11.3 \pm 0.5$ \\
\hline & 2007 & 5 & Liza aurata & $259 \pm 72$ & $285 \pm 37$ & $100 \pm 11$ & $11.2 \pm 1.7$ \\
\hline
\end{tabular}

${ }^{\mathrm{a}}$ pmol $\mathrm{min}^{-1} \mathrm{mg}^{-1}$ protein

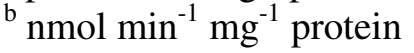


Table 2 Total PAH concentrations in the livers of mullets collected from six sampling stations of the West Black Sea Coast of Turkey in 2006. Homogenous subsets (groups do not differ significantly) were indicated by the same letters $(\mathrm{p}<0.05)$.

\begin{tabular}{cccc}
\hline Zone & N & Fish Species & $\begin{array}{c}\text { PAH } \\
\text { Concentration * }\end{array}$ \\
\hline Zonguldak Harbour & 13 & Mugil soiuy & $54 \pm 5(\mathrm{a})$ \\
& 9 & Liza aurata & $47 \pm 6(\mathrm{a})$ \\
Ereğli Harbour & 12 & Liza aurata & $28 \pm 3(\mathrm{~b})$ \\
Gülüç Stream Mouth & 11 & Mugil soiuy & $35 \pm 3(\mathrm{ab})$ \\
Melen Stream Mouth & 9 & Mugil soiuy & $25 \pm 3(\mathrm{bc})$ \\
Sakarya River Mouth & 8 & Mugil soiuy & $21 \pm 3(\mathrm{bc})$ \\
Amasra & 3 & Mugil soiuy & $12 \pm 2(\mathrm{c})$ \\
& 4 & Mugil cephalus & $11 \pm 2(\mathrm{c})$ \\
\hline * & & &
\end{tabular}

$* \mu \mathrm{g} \mathrm{g}^{-1}$ dry weight 


\section{FIGURE LEGENDS}

Figure 1 Fish sampling stations in the West Black Sea Coast of Turkey. * Reference site.

Figure 2 Ethoxyresorufin O-deethylase (EROD) activities of liver microsomes of mullets caught from six sampling stations of the West Black Sea Coast of Turkey in 2005, 2006, and 2007. Homogenous subsets (groups do not differ significantly) were indicated by the same letters $(\mathrm{p}<0.05)$.

Figure 3 Western blot analysis of CYP1A protein contents and correlation between microsomal EROD activities and CYP1A protein levels of mullets caught from different stations of the West Black Sea Coast of Turkey in 2005 (A), 2006 (B), and 2007 (C). $80 \mu \mathrm{g}$ microsomal protein was applied to each slot. (A) Line 1-9 (Mugil so-iuy) and Line 10-12 (Liza aurata); (B) Line 1-7 (Mugil so-iuy) and Line 8-12 (Liza aurata); (C) Line 1-4 (Liza aurata), Line 5-8 (Mugil so-iuy), Line 9-12 (Mugil cephalus).

* Sampled in 2006

** Sampled in 2007

Figure 4 Comparison of anti-leaping mullet CYP1A cross reactivity pattern of different mullet species. The intensities of CYP1A protein bands of different mullet species present in the same western blot result (Figure 3C) were compared together with corresponding EROD activities and EROD activity/CYP1A protein level (R.P.A.) ratios. Different mullet species having similar EROD activity showed similar degree of staining and gave almost the same EROD activity/CYP1A protein level (R.P.A.) ratio.

Figure 5 Glutathione S-transferase (GST) activities of mullets caught from six sampling stations of the West Black Sea Coast of Turkey in 2005, 2006, and 2007. Homogenous subsets (groups do not differ significantly) were indicated by the same letters $(\mathrm{p}<0.05)$.

Figure 6 Catalase activities of mullets caught from six sampling stations of the West Black Sea Coast of Turkey in 2005, 2006 , and 2007. Homogenous subsets (groups do not differ significantly) were indicated by the same letters $(\mathrm{p}<0.05)$.

Figure 7 Glutathione reductase activities of mullets caught from six sampling stations of the West Black Sea Coast of Turkey in 2005, 2006, and 2007. Homogenous subsets (groups do not differ significantly) were indicated by the same letters $(\mathrm{p}<0.05)$. 
Figure 1

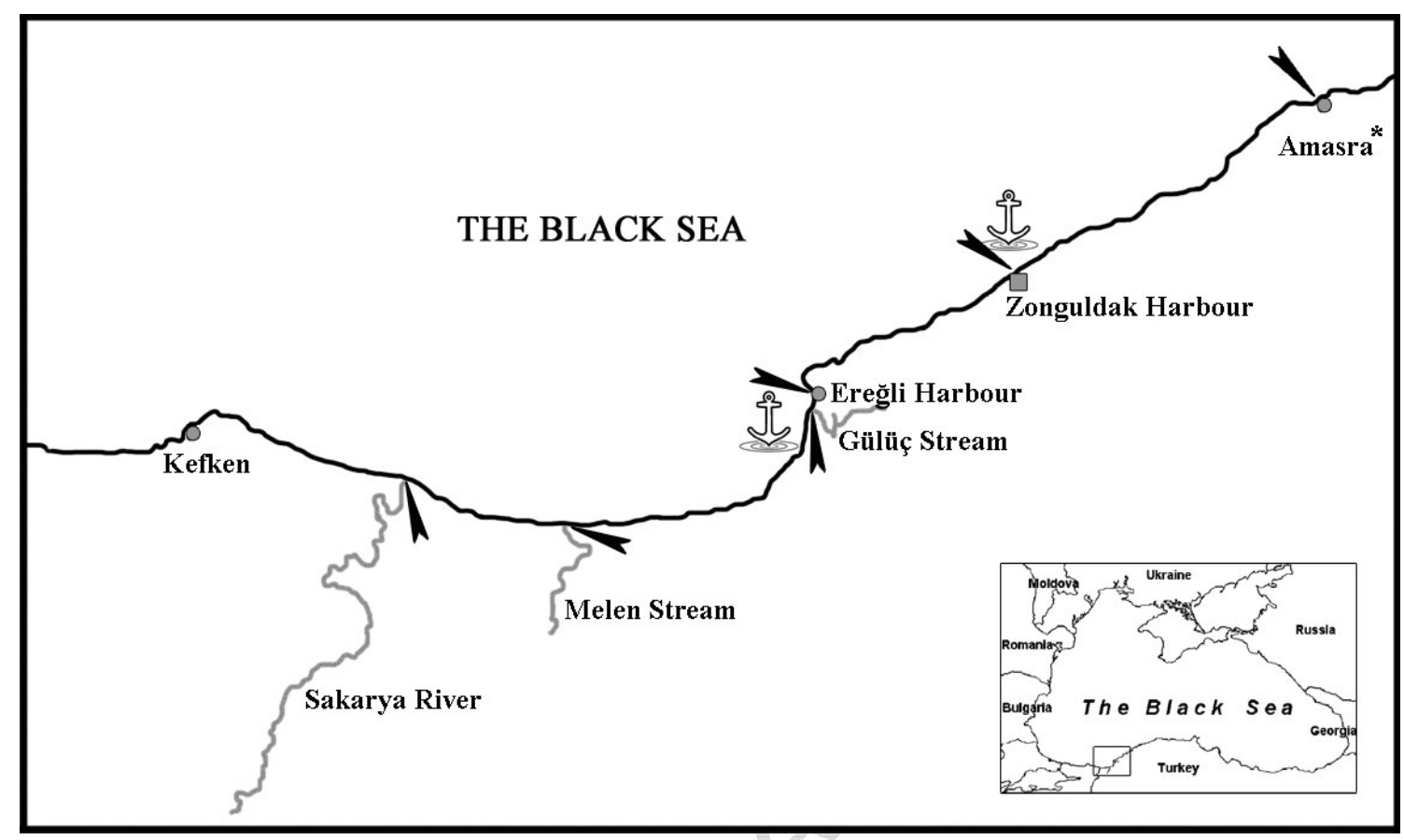


Figure 2

\section{EROD Activities of Mullets}

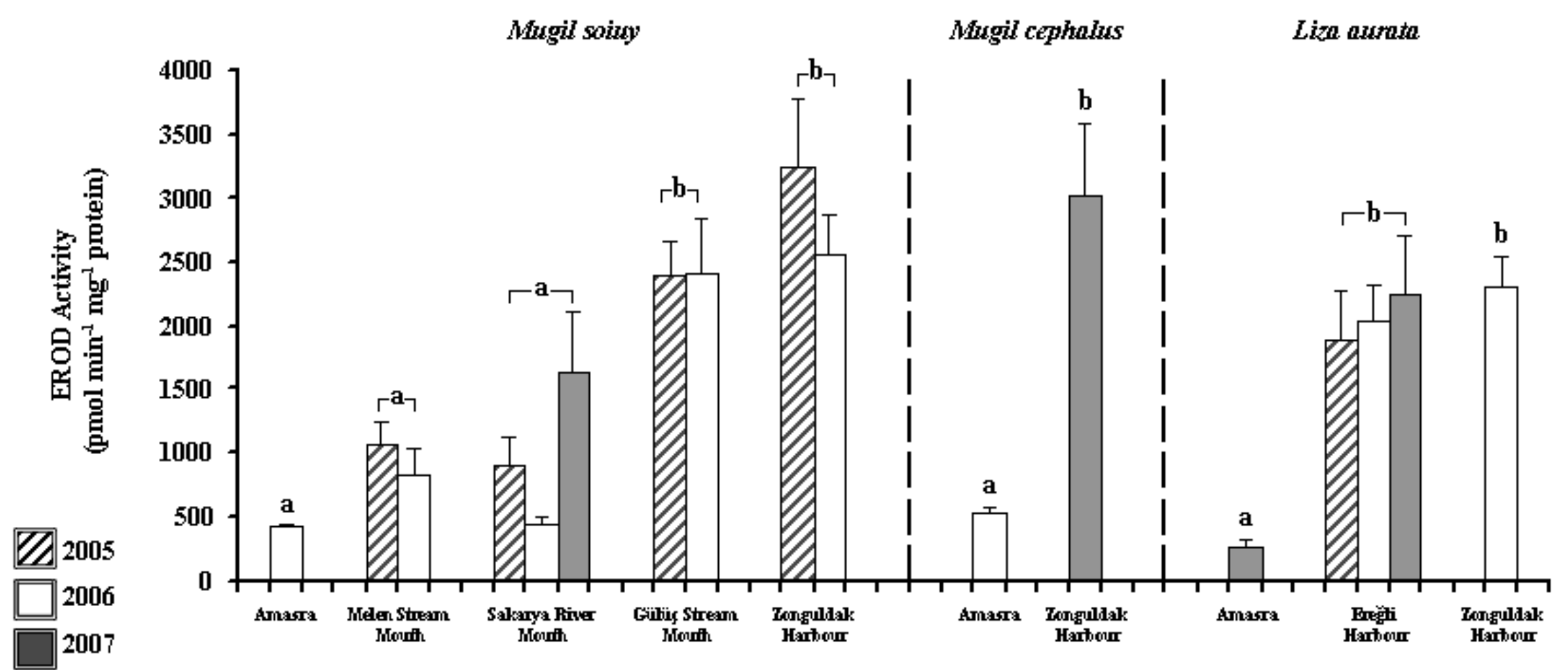




\section{Figure 3}

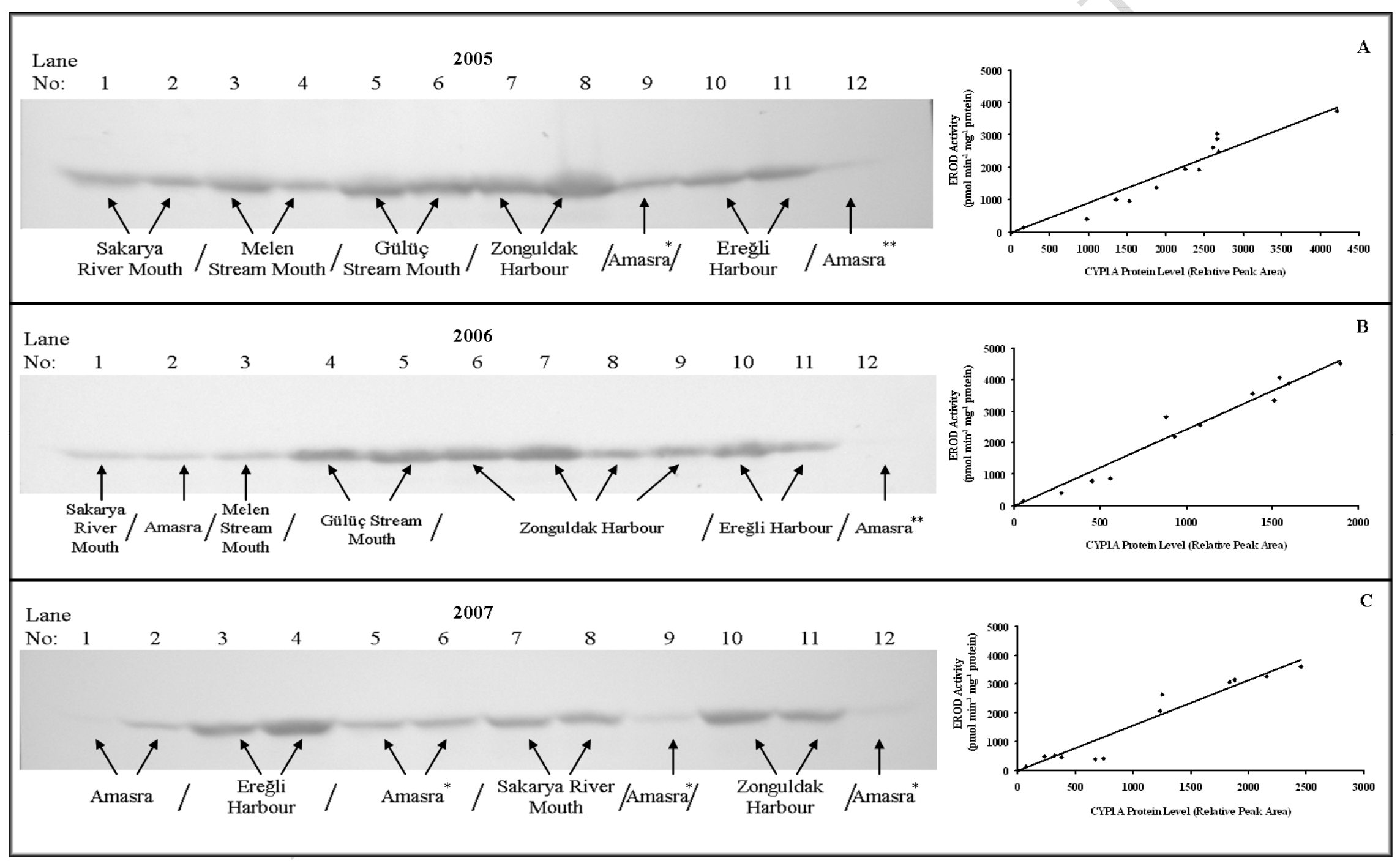


Figure 4

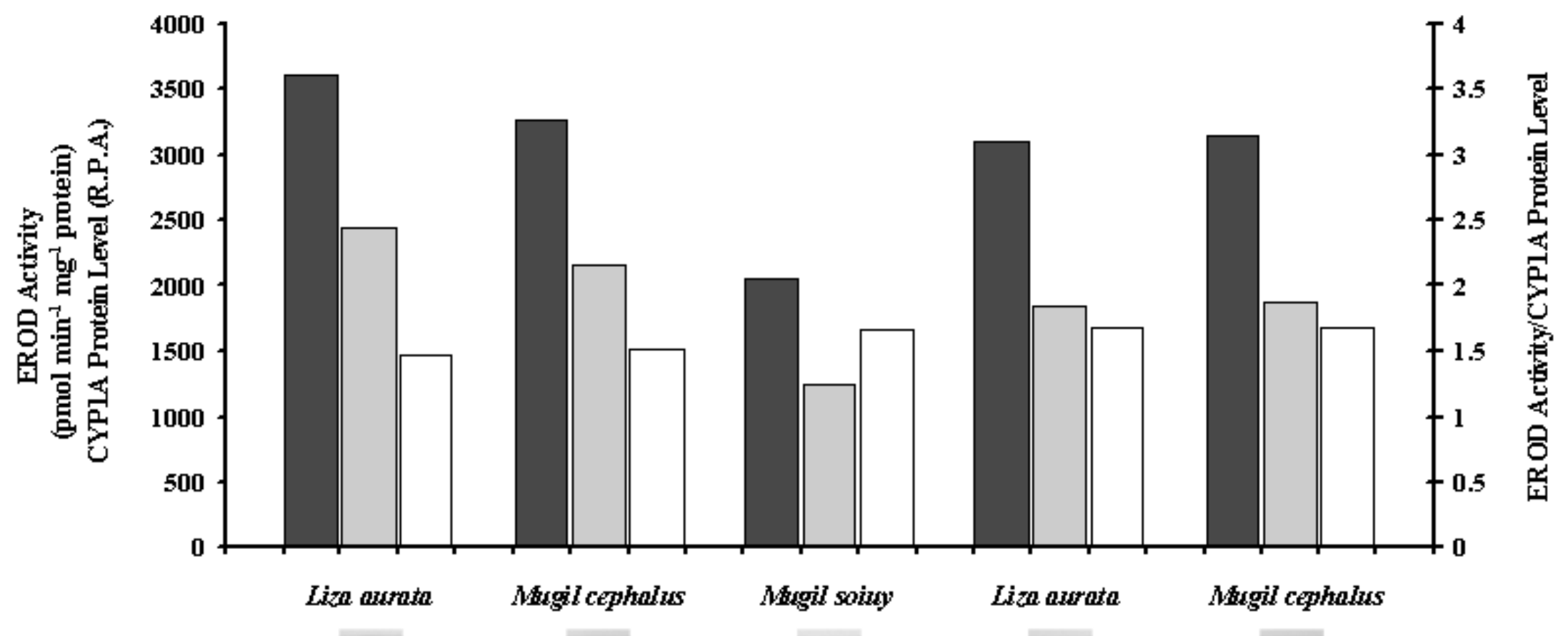

EROD Activity (pmol min ${ }^{-1} \mathrm{mg}^{-1}$ protein)

$\square$ CYPIAprotein level (R.P.A)

$\square$ EROD Activity/CYPIA protein level 
Figure 5

\section{Total Glutathione S-Transferase Activies of Mullets}

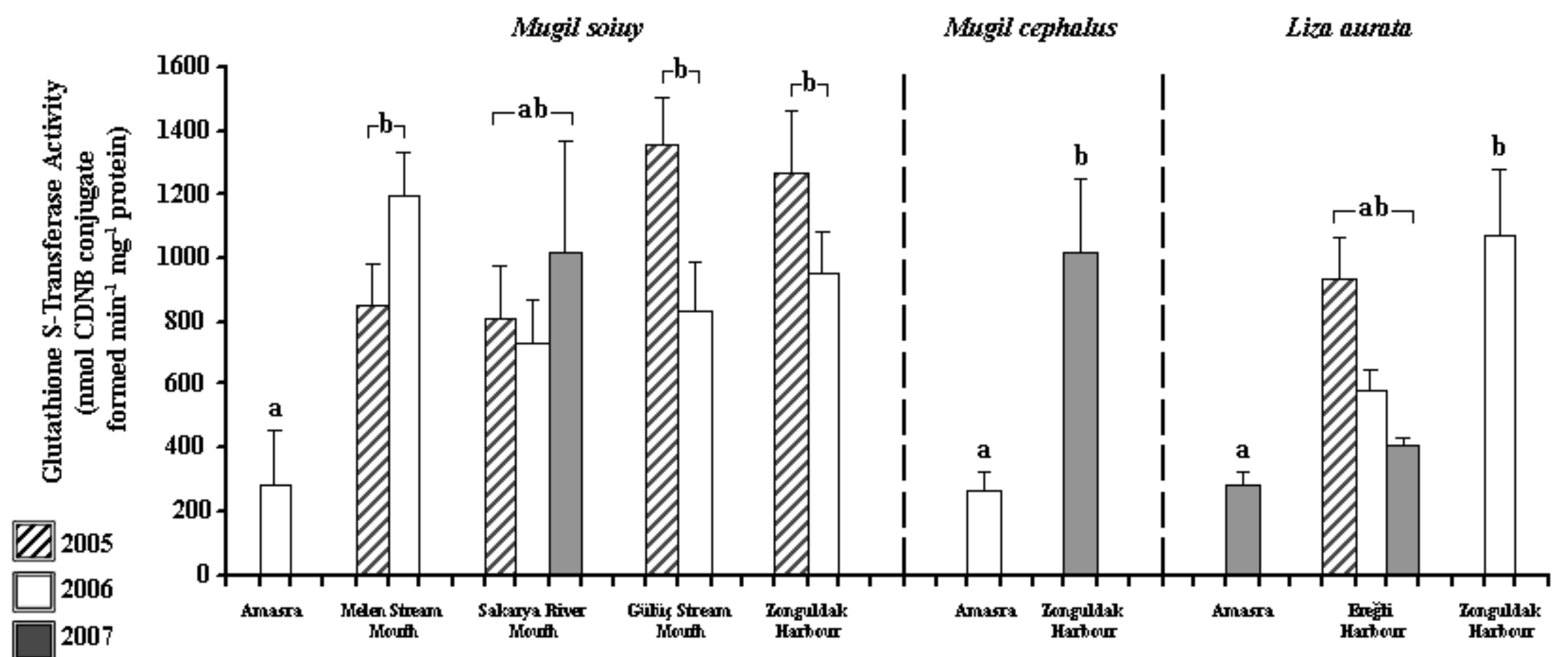


Figure 6

Catalase Activities of Mullets

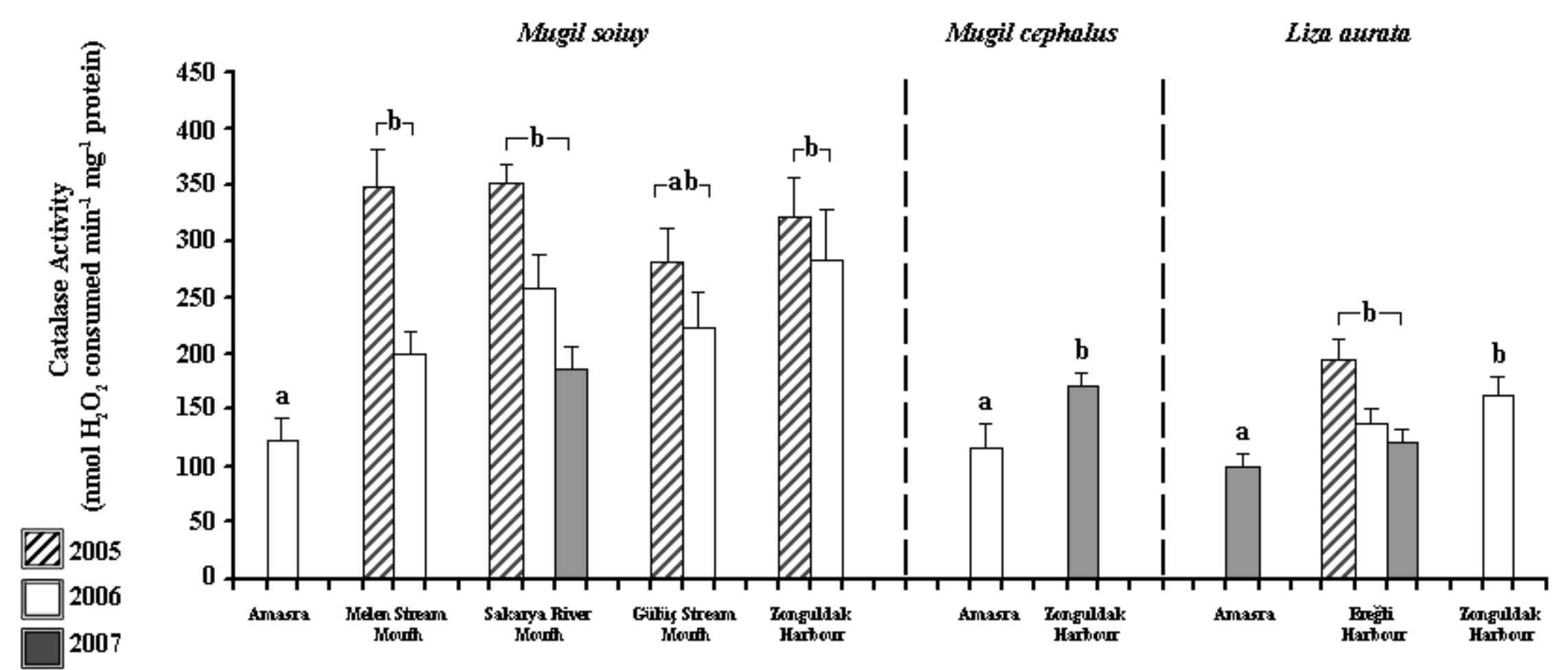


Figure 7

\section{Glutathione Reductase Activities of Mullets}

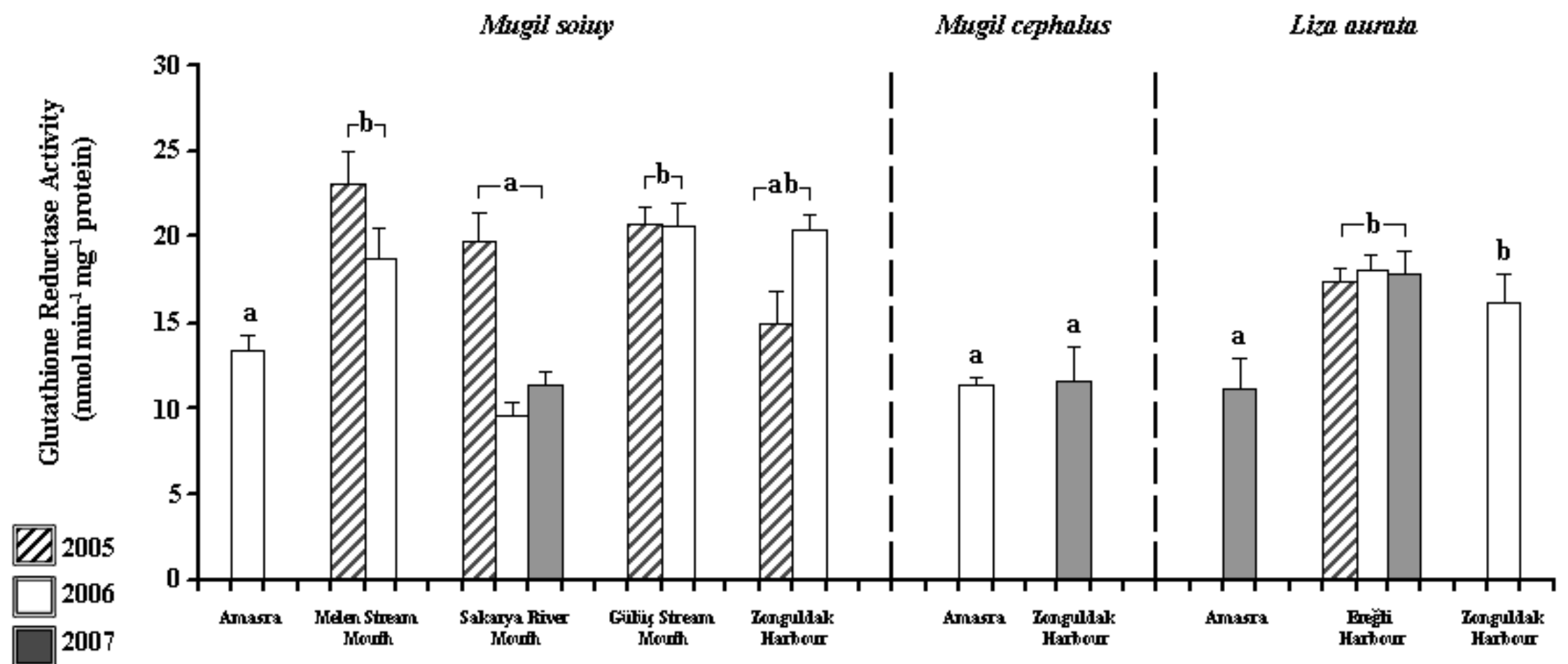

